\title{
De cor e salteado: oralidade e memória do circo
}

Walter de Sousa Junior

Professor doutor pela Escola de Comunicações e Artes da USP. Pós-doutorando da mesma instituição com bolsa Fapesp, desenvolve a pesquisa Entre o contemporâneo e o grotesco: Piolin e as comédias de picadeiro encenadas entre 1933 e 1960.

E-mail: waltersousajr@hotmail.com

Resumo: Analisar a oralidade na construção da cultura circense, especialmente nos processos de socialização e identificação, é o objetivo deste artigo, que tem por base o acervo do Arquivo Miroel Silveira e os depoimentos dos artistas de circo.

Palavras-chave: Identidade, oralidade, circo, circo-teatro, memória.
Abstract: To analyze the construction of orality in culture circus, especially in the processes of socialization and identification is the goal of this article, which is based on the collection of Archive Miroel Silveira and the depositions of the circus artists.

Keywords: Identity, orality, circus, circus theater, memory.

"Todas as histórias contadas pelo narrador inscrevem-se dentro da sua história, a de seu nascimento, vida e morte"1.

"Vou logo falar uma coisa... Eu começo a contar... eu nunca tenho tempo pra contar tudo essas histórias todas... E eu quero contar... principalmente quando falo de uma coisa e me lembro de outra. (...) O pior é que eu conto e depois não lembro o que eu tava contando antes...”2.

O fazer circense, inegavelmente, está ligado ao corpo, à habilidade física de se buscar o sublime - mesmo o palhaço, que encontra matéria do riso no grotesco, precisa dispor da condição do sublime corporal. "O circense é sempre aquele que foi mais além de alguma de nossas impossibilidades físicas, na elevação, no salto, na coragem, na força, no equilíbrio, na manipulação da magia, no domínio da natureza animal", define Miroel Silveira. Como a condição do sublime está diretamente ligada ao risco (de vida, no caso do circense), o mesmo autor adverte: "O risco permanente, que é inarredável da profissão, exige não apenas aperfeiçoamento corporal, mas principalmente a higidez da mente"

Todo o conhecimento circense está guardado na memória coletiva dos artistas, em geral familiares com anos de experiência, enquanto a sua forma específica de perpetuação é a oralidade. É interessante presenciar uma reunião de antigos artistas circenses: do nada, entre um diálogo e outro, eles passam a elevar a voz e a declamar, em tom de alegre desafio, trechos inteiros das

2. Depoimento de Roger Avanzi, concedido em sua casa, em São Paulo, em 21 de maio de 2008, a este pesquisador.

3. SILVEIRA, Miroel. O circo: espaço arquetipal convergente. In: $\mathrm{O}$ circo. Secretaria da Cultura, Ciência e Tecnologia do Estado de São Paulo, 1978.

4. Ibid. 
comunicação \& educação • Ano XVI • número 2 • jul/dez 2011

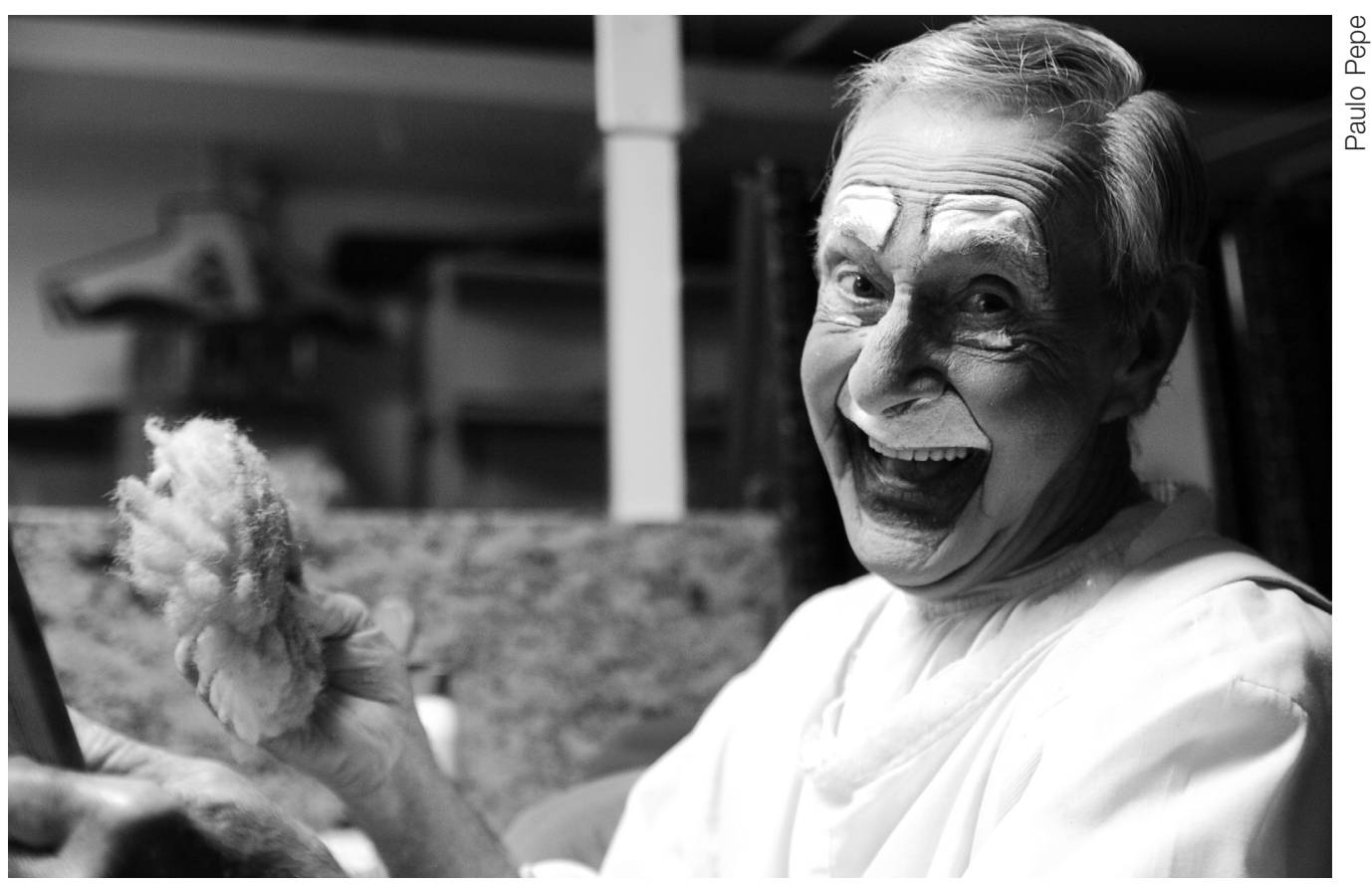

Roger Avanzi, o palhaço Picolino II.

peças clássicas de circo-teatro. Estas podem ter diálogos rimados, como os de O mártir do Calvário, do português Eduardo Garrido, ou emocionalmente pomposos, como os de Sílvio, o cigano, do também lusitano Velloso da Costa, ou ainda ganhar um tom épico, como no caso de Os dois sargentos, de Theodóre D’Aubigny. O palhaço Picolino II (Roger Avanzi), em entrevista concedida a este pesquisador, não se furtou a recitar trecho de um dos grandes clássicos encenados na maior parte dos grandes circos brasileiros durante as décadas de 1930 a 1970, Honrarás tua mãe, driblando as falhas de memória e fazendo valer os anos de atuação nos palcos e picadeiros: "Não sei se é da peça ou se foi adaptado. Quando terminava a peça, terminava bem, a mãe reconhecia o filho, mandava o filho casar com a... aquela apoteose ali, né? $\mathrm{E}$ a última cena, era o irmão ruim que fazia maldade com a mãe. 'Meu irmão, de hoje em diante nossa mãe honrarás!', tinha que falar. Aí terminava, o povo aplaudia e tinha que ficar quieto. Eu vou ver se me lembro da última fala que eu fazia, que eu acho que era adaptação. As personagens todas ficavam paradas, quietas, e eu ia avançando. E era picadeiro. E falava direto com a plateia. Eu dizia: 'E vós, chefes de famílias, não leveis a mal as poucas palavras que irei dizer. Mas dai educação aos vossos filhos para que mais tarde não aconteça quadro tão horrível como este que acabastes de ver. A ponto de um filho internar a sua própria mãe num asilo. E todos, moços e moças, meninos ou meninas, se quiserdes ser felizes, e triunfares na vida, honrarei as vossas mães!'. Aí o circo vinha abaixo! Era um sucesso! Eu gostava muito"

Cotejando com o texto original, de fato a apoteose não existe, de modo

5. Depoimento de Roger Avanzi, cit. que a peça termina, como sinalizou Avanzi, com a fala de Roberto, o bom filho do texto de Romano Coutinho: "Vês Edgard [o mau filho], como sou 
feliz, tudo favorece ao bom filho. Que esta te sirva de lição e de exemplo, de hoje para o futuro, se quiserdes ser feliz nunca te esqueça do quarto mandamento da lei de Deus: 'Honrarás tua mãe"' . A apoteose era comum às peças religiosas, quando o artista circense se valia da comoção geral para dar uma instrução de cunho moral que fizesse transbordar o sentimento até ali contido pela plateia. Embora não tenha uma apoteose, Honrarás tua mãe, por seu fundo religioso, acabou ensejando aos circenses que recitassem um texto final. Não fosse a memória oral de Avanzi, não se conheceria tal apoteose da peça nas inúmeras vezes em que foi encenada sob a lona do Circo Nerino (1913-1984).

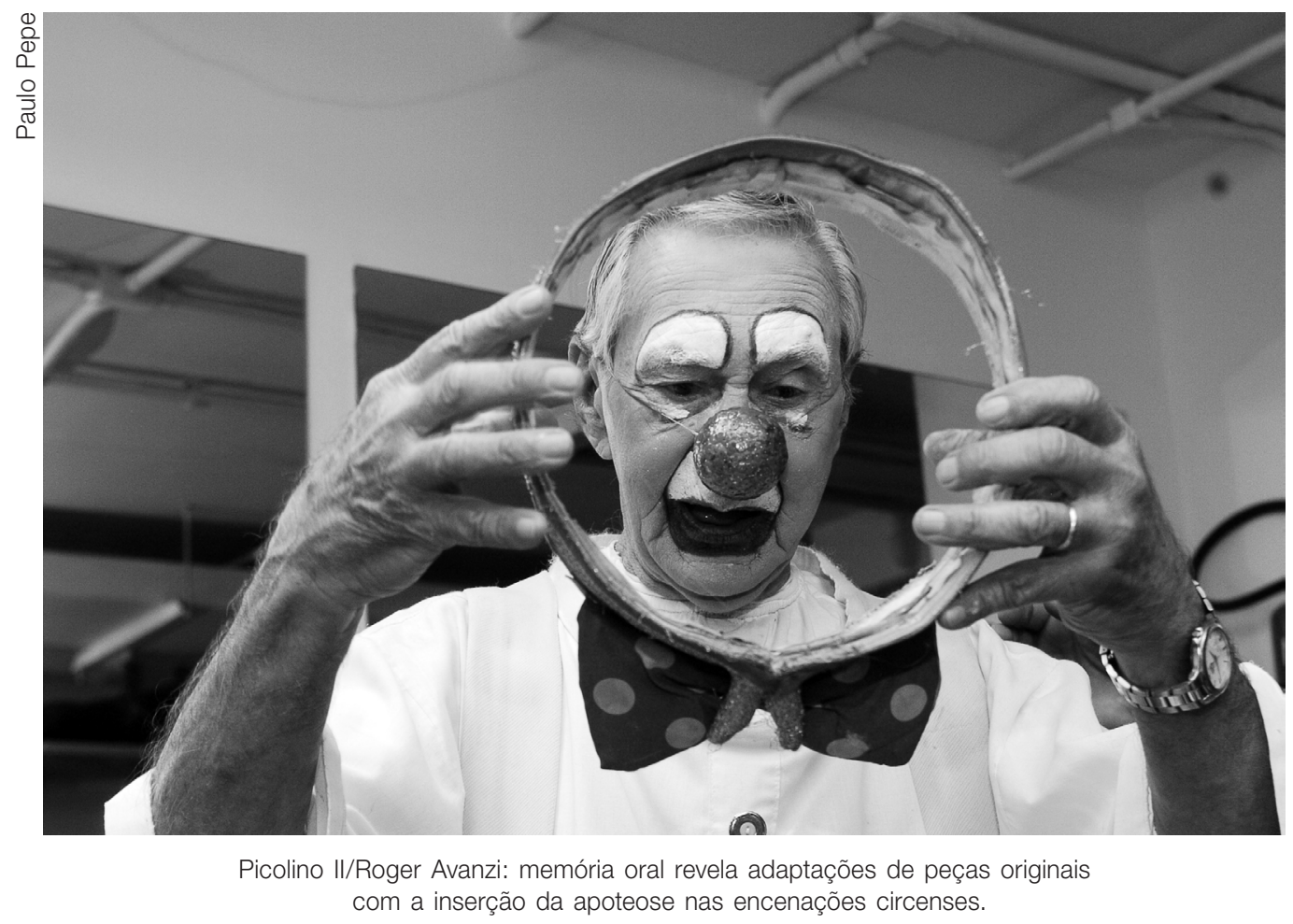

A operação da recitação entre circenses remete à cena final do filme Fahrenheit ${ }^{7}$ 451 (1966), de François Truffaut. O personagem principal, Montag, um bombeiro encarregado de incendiar livros - e aqui se evidencia a grande ironia do filme e do livro homônimo de Ray Bradbury, escrito em 1953 - a inversão -, descobre, ao final, a terra dos homens-livro, local onde um grupo de resistência à ditadura futurista se dedica a decorar e repetir a íntegra dos clássicos banidos para que não sejam esquecidos. O filme inverte a equação temporal, apontando a oralidade, que historicamente precedeu o registro escrito, como o antídoto para conter a estrutura do poder instituído para banir os livros que, ameaçadoramente, estimulam o exercício crítico dos cidadãos.

A evidência do contraste dessa comparação entre o filme e a memória oral dos circenses se intensifica quando a maior parte do repertório de peças de circo-teatro encenadas em São Paulo e no Brasil, que se imaginava perdida no tempo, após tanto perambular junto com a bagagem das companhias, é resgatada a partir dos processos de censura do Departamento de Diversões Públicas
6. COUTINHO, Romano. Honrarás tua mãe. Parte integrante do Prontuário 1286 do Arquivo Miroel Silveira da ECA/USP.

7. Sobre o filme, ver a videografia indicada em: MAGNO Maria Ignês Carlos. Fahrenheit 451. Escritores da Liberdade e uma discussão sobre leitura, escrita, imaginação, resistência e liberdade. Comunicação \& Educação, ano XIV, n. 1, jan./ abr. 2009. São Paulo: CCA-ECA-USP/Paulinas. 
comunicação \& educação • Ano XVI • número 2 • jul/dez 2011

do Estado de São Paulo. Eles perfazem o acervo do Arquivo Miroel Silveira, da Biblioteca da Escola de Comunicações e Artes da USP ${ }^{8}$. São 1.080 peças cujos processos datam entre os anos 1928 e 1968. E que se mantém como repositório da dramaturgia circense, revelando versões de peças e o texto original, que ressurge sob a rasura dos lápis vermelhos e carimbos de Censure-se. Finda a censura, o arquivo se transformou em fonte de pesquisa e conhecimento, pois o período histórico brasileiro, que inclui duas ditaduras - a de Vargas (19371945) e a Militar (1964-1986) -, felizmente não controlou a produção artística com bombeiros incendiários, muito embora parte da dramaturgia continue escapando das conversas animadas dos circenses, estes que têm o texto na ponta da língua.

\section{SOCIALIZAÇÃO E IDENTIDADE}

Ao saber o texto de cor e salteado, o circense usa a prática requerida para a sua atividade profissional como um sistema reforçador da sua identidade, pois, ao recitar o texto, este já faz parte dele, de sua personalidade artística - é o personagem que fala por ele, e ele, ao relembrar o texto, fala pelo personagem -, de modo que identificação e alteridade se confundem num jogo de memória em que as cartas e suas posições são conhecidas de antemão, o que não tira a graça do exercício. É a relação entre memória e oralidade.

Camadas de memória se sobrepõem quando, por exemplo, Benedito Sbano, o palhaço Picoly e ator do Pavilhão Teatro Popular Volante, rememora uma ocasião em que saber os textos de cor e salteado foi elemento de identificação e solucionador de um impasse para a instalação do seu circo: "Eu fui procurar um terreno aqui em São Paulo para o circo. Eu secretariava também o circo. Eu não sabia de quem era e perguntei num barzinho: 'De quem é esse terreno?'. Ele disse: 'Olha, tá vendo aquele armazém ali, pegado ao terreno? É do seu Martelo'. Eu já tinha falado que era pra circo. Ele disse: 'Se for pra circo, não vai falar, não. Houve problemas com um circo que esteve aqui'. (...) Eu disse: 'Mas, e o seu Martelo,

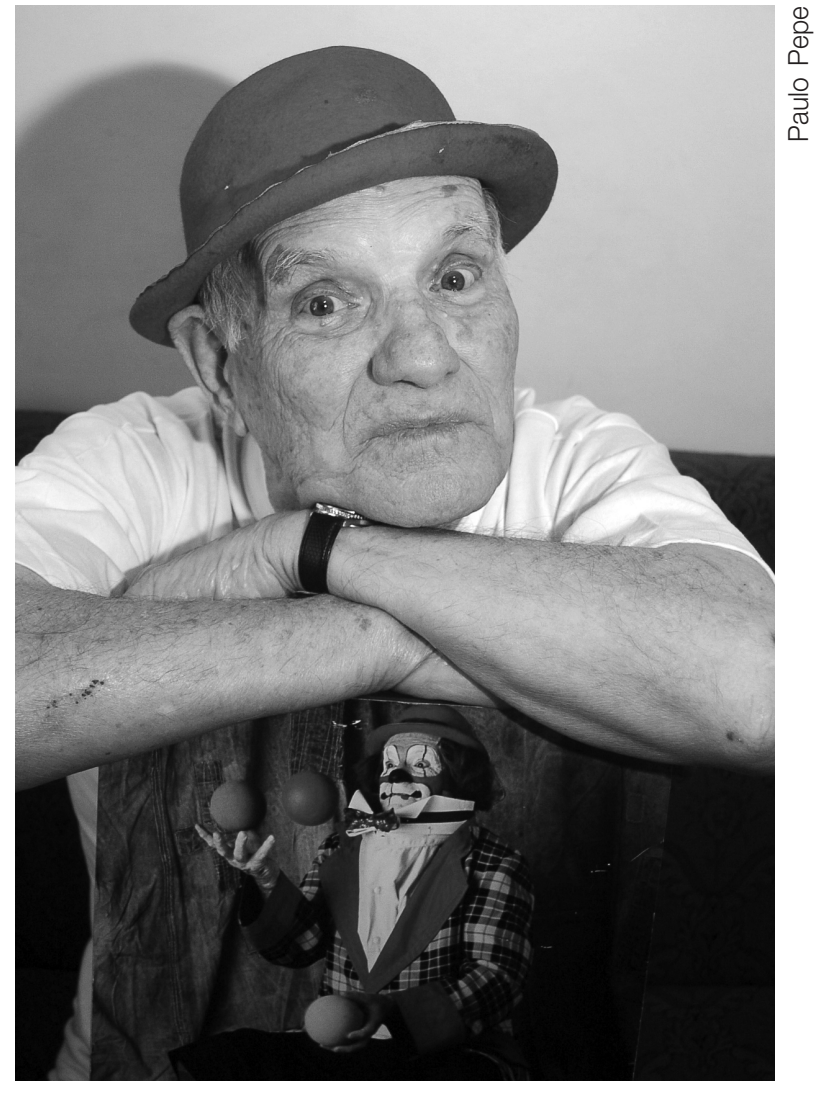

Benedito Sbano, o palhaço Picoly 
o que ele é na vida, o que ele gosta, o que ele faz?'. 'Ele foi amador de teatro.' Antigamente, em toda a cidade havia aqueles grupos de amadores. Formavam grupos muito bons até. 'Ah, ele foi de teatro?' 'Foi.' Aí eu fui lá e... 'Seu Martelo, como vai?', e aquela coisa toda. 'Pois é, seu Martelo, eu sou de circo' - não deixei de falar... 'Eu estive até falando com aquele senhor e ele contou o que houve aqui, né? É um problema essas coisas, o senhor vê... o circo precisa de alguém que ceda o terreno... A Prefeitura é mais difícil, quando vem a ordem pra entrar, a gente já mudou, não precisa mais...' Aí eu disse: 'Nós somos circo-teatro. Aliás eu soube que o senhor também é artista'. 'Não, não, só fui amador...' Mas, seu Martelo, o senhor sabe de uma coisa, existem amadores melhores que artistas! 'O senhor falou a verdade!' Aí começou... O senhor foi amador aqui mesmo em São Paulo? 'Foi aqui mesmo. No interior também.' Eu disse: 'Aquelas peças bonitas que se levava... O senhor lembra? Ele disse: 'Sim, lembro.' Aí perguntou: 'O senhor conhece Os dois sargentos?' Eu disse: 'Eu fiz o Roberto'. Ele disse: 'Eu fiz o Guilherme!'. Eram os dois principais. Eu disse: 'O senhor lembra daquela parte em que o Roberto dizia: 'E agora, miserável, pode ordenar a execução' - é mais ou menos isso, não me lembro bem, 'que se faça a execução!', por aí assim'. E ele já começou a falar também o pedaço das peças, né? Eu daqui, ele de lá. Eu digo: 'E Silvio, o cigano?'. 'Puxa vida, eu fiz o pai do cigano!' E eu fiz o Silvio! Para não encompridar mais, de repente ele falou pra mim: 'Olha, eu tenho certeza que o senhor vai se dar bem aqui no meu terreno!"”.

Segundo Henri Bergson, quando se evoca o passado, a ação, o ambiente e o corpo daquele passado povoam as memórias. Mas nem sempre eles são trazidos para o presente. Ele é mediado pela imagem do corpo, assim como a ação deste em relação ao ambiente evocado. Mas nem sempre esse processo de ação do corpo é transportado para o presente. “(...) a memória permite a relação do corpo presente com o passado e, ao mesmo tempo, interfere no processo 'atual' das representações"10. Há, portanto uma interferência transtemporal. Ecléa Bosi destaca, ao analisar Bergson, que a memória não ocorre de forma homogênea. Existe uma memória-hábito, feita de esquemas de comportamento que o corpo emprega para agir conforme o ambiente. "Ela é (...) um processo que se dá pelas exigências da socialização. Trata-se de um exercício que, retomado até a fixação, transforma-se em um hábito, em um serviço para a vida cotidiana"11. Por exemplo, ter o texto teatral decorado para uma ação de representação. E há a memória que independe de qualquer hábito, evocativa, que promove "autênticas ressurreições do passado"12. Por exemplo, recitar um texto já encenado diversas vezes no passado, de modo que cada palavra evoque situações e imagens daquele tempo.

Considerando esse esquema bergsoniano, é possível separar as camadas de memória presentes na narrativa de Sbano: ao lembrar o caso como uma experiência pessoal em que há um processo de identificação - elevado pelo narrador ao nível anedótico -, este se dá, evocativamente, por meio da recitação do texto teatral. Ao mesmo tempo, o próprio ato da recitação se refere a um processo social: ele tem o texto na ponta da língua por ser uma exigência do seu exercício laborativo. No entender de Bergson, a memória-hábito se apropria
9. Depoimento colhido durante o projeto "Entre risos e lágrimas - $O$ teatro no circo (da pantomima aos dramas)", realizado em outubro de 2010, a partir de uma parceria entre o Centro de Memória do Circo, da Secretaria Municipal de Cultura de São Paulo, e o NPCC Arquivo Miroel Silveira.

10. BOSI, op. cit., p. 46-47. 11. Ibid., p. 49.

12. Ibid., p. 48. 


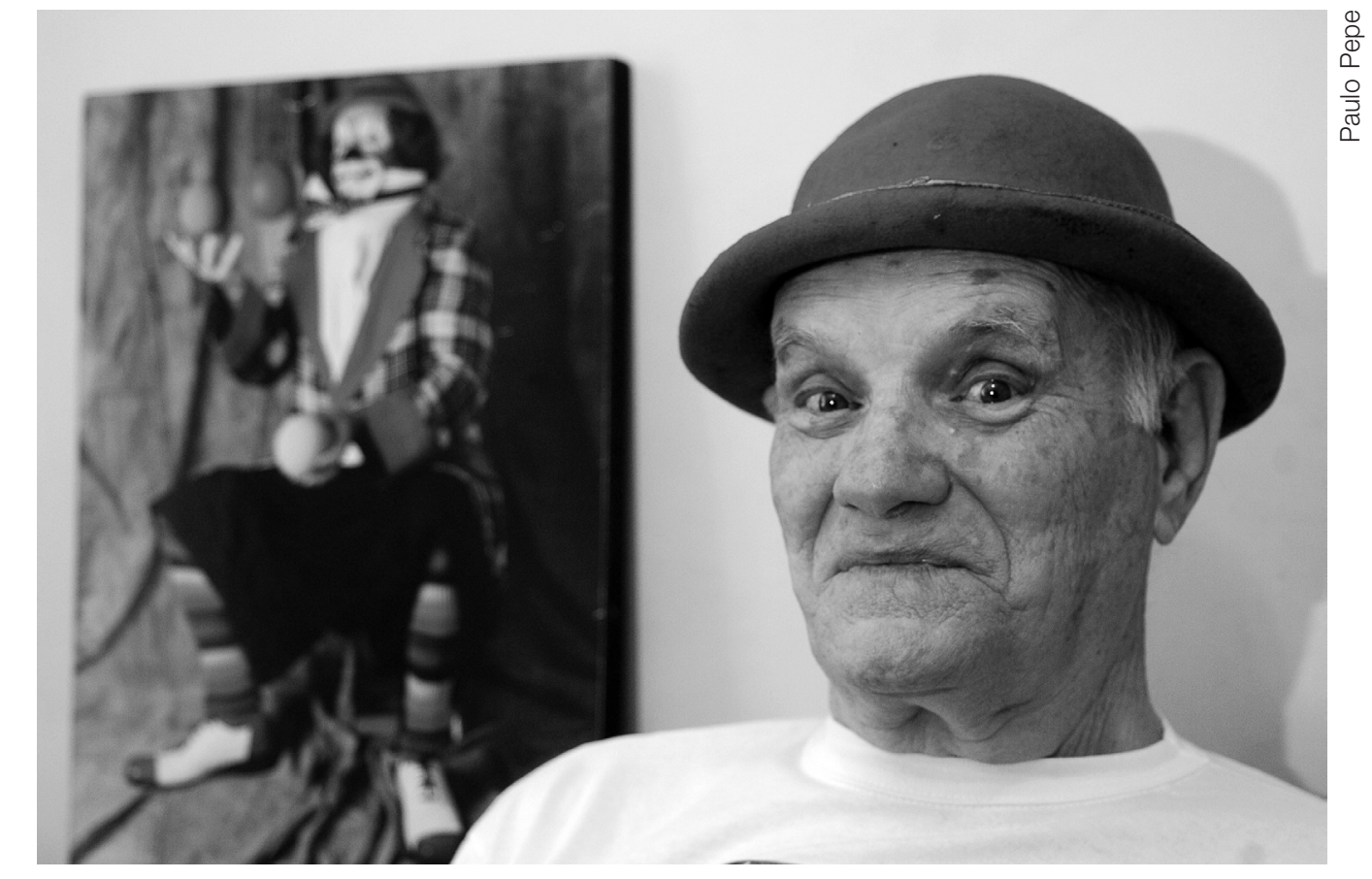

Sbano/Picoly: texto na ponta da língua, sobreposição de socialização e identidade.

da memória contemplativa. No caso de Sbano, por sua vez, há um efeito liberador: a memória-hábito desencadeia a memória contemplativa. Socialização e identidade decorrem dessa sobreposição.

Como aponta Cristina Costa,

(...) as estruturas narrativas são formas de estabelecer modulações e durações, arquitetando a temporalidade humana. São essenciais para a construção da identidade, tanto a individual como a coletiva, pois, a partir das considerações feitas, ser para o homem é ter uma história, é integrar durações e temporalidades ${ }^{13}$.

Embora a narrativa desses homens-livros não seja autoral, mas a rememoração de um texto por demais repetido nas representações cênicas, ela se torna construção identitária do narrador, pois é evocativa. O narrador estetiza a lembrança, pois não narra simplesmente, mas interpreta ao recitar.

13. COSTA, Cristina. A milésima segunda noite. São Paulo: AnnaBlume, 2000. p. 41.

14. Ibid., p. 41-42.

15. SILVA, Ermínia. O circo: sua arte e seus saberes. O circo no Brasil do século XIX a meados do XX. Dissertação (Mestrado). Departamento de História do Instituto de Filosofia e Ciências Humanas da Universidade Estadual de Campinas, 1996. p. 77.
A narrativa artística é aquela que constrói uma metáfora da duração humana não só como conteúdo (...) mas também como forma. Reconhecer uma narrativa como estética é descobrir-lhe a transposição da temporalidade para a construção da sua forma expressiva $(. . .)^{14}$.

\section{SABERES ORAIS}

A oralidade faz parte de todo o aprendizado circense, pois a nova geração de artistas se faz a partir dos mestres da geração anterior, aqueles que guardam a tradição. Ermínia Silva explica que a transmissão dos saberes se dá de maneira formal e oral. 
Os circenses sempre indicam uma figura que se responsabilizava e possibilitava que se tornassem profissionais do picadeiro. $\mathrm{O}$ condutor do processo de aprendizagem que formava um artista era considerado um mestre. Mestre da arte circense, mestre de um modo de vida, mestre em saberes - ou seja, um mestre "pertencente à tradição", pois durante toda a sua vida participou das experiências de socialização/formação/aprendizagem que caracterizam o circo-família. ${ }^{15}$

Aqui, mais uma vez, confunde-se socialização e identidade, pois:

é característica da fala dos circenses, quando relatam seu processo de aprendizagem, não distinguir momentos formais de aquisição de conhecimentos, incluídos os treinos e os ensaios: tudo isto é trabalhar. Talvez seja por isto que se dizem artistas desde o nascimento ${ }^{16}$.

É importante salientar que a transmissão oral dos saberes circenses faz uma passagem instantânea da memória oral para a memória corporal, pois estes saberes estão conectados às habilidades físicas do aprendiz: é por meio delas que se estabelece um vínculo identitário com a tradição circense, pois é a aprendizagem que "identifica o circense como artista, é o procedimento que conduz ao domínio da técnica envolvida nas artes circenses, um dos fundamentos do circo-família"17.

No entanto, não há como compreender essa transmissão como um processo de alimentação da memória-hábito, pois ela agrega a interação social, que gera um efeito corporal, físico. Ou seja, a experiência acumulada das gerações circenses, expressa pelo mestre na formação do aprendiz, está carregada do componente cultural - a tradição -, e é a partir dele que se absorve a aprendizagem e se desenvolve a habilidade física. Finalmente, estabelece-se o vínculo entre memória, oralidade e cultura.

\section{MEMÓRIA ORAL ESCRITA}

A partir da década de 1970, quando a classe circense passa a se preocupar com a perenidade dos saberes circenses e da história das famílias e companhias, pois os circos começam a sucumbir à força dos meios de comunicação de massa e ao crescimento das cidades - que fazem desaparecer os terrenos para a montagem das lonas -, tem início o surgimento de publicações, muitas vezes financiadas pelos próprios autores, com um tipo de escrita memorial, quase oral. A partir do livro O circo - A pitoresca turnê do Circo Garcia através da África e países asiáticos, de Antolim Garcia, que contava, de forma romanceada, a dita aventura, diversos outros depoimentos, escritos em tom francamente memorial, passaram a ser publicados num período que se estende até o final do século $\mathrm{XX}^{18}$. Alguns trechos revelam que se trata, de fato, de memória oral registrada pela escrita [os grifos são do autor do artigo]:

Sempre falo sobre circo, todas as vezes que posso, o circo está dentro de mim, da minha vida, do meu presente e do meu passado. (...) Aqui está, portanto, o meu depoimento sobre a arte circense, o circo brasileiro e suas memórias ${ }^{19}$.
16. Ibid., p. 76.

17. Ibid., p. 91-92.

18. Os demais livros publicados foram: SEYSSEL, Waldemar. Arrelia e o circo. São Paulo: Melhoramentos, 1977; MILITELLO, Dirce Tangará. Picadeiro. São Paulo: Edições Guarida, 1978; Id. Dirce Tangará. Terceiro sinal. São Paulo: Mercury Produções Artísticas,1984; NETO, Tito. Minha vida no circo. São Paulo: Editora Autores Novos, 1986; ORFEl, Alberto. O circo viverá. São Paulo: Mercuryo, 1996; SEYSSEL, Waldemar. Arrelia, uma autobiografia. São Paulo: Ibrasa, 1997; BARTHOLO, Ruy. Respeitável público: os bastidores do fascinante mundo do circo. Rio de Janeiro: Letras \& Expressões Editora, 1999.

19. MILITELLO, op. cit., p. 1. 
comunicação \& educação • Ano XVI • número 2 • jul/dez 2011

\begin{abstract}
Meus filhos, minha esposa, meus familiares, enfim, sempre que eu contava as passagens pitorescas acontecidas em minha atribulada carreira de "homem dos sete instrumentos" - diziam-me: "Você deve escrever um livro contando essas coisas engraçadas, essas passagens alegres e tristes acontecidas em sua vida" ${ }^{20}$.

Quando comecei a escrever este livro, não sabia direito o que iria escrever; só sentia a necessidade de falar sobre a nossa vida, a vida do circo vista sob o enfoque de alguém que a viveu. (...) Então decidi que iria escrever tudo o que viesse à minha cabeça e que achasse que seria interessante para descrever a vida no circo, sem uma ordem preestabelecida ${ }^{21}$.
\end{abstract}

Alcança-se aí um novo patamar, forçado pelas circunstâncias históricas que vivia o circo: registra-se a memória oral para as gerações futuras, sem a ação direta do mestre junto ao aprendiz. Resta ainda a evocação do passado para servir de lição para o futuro. Substitui-se o campo da troca direta pelo da troca mediada - o livro conta - e, mais uma vez, a prática circense, que apesar de se basear na tradição, não hesita em absorver influências da cultura que não é dela, mas dos meios de comunicação, lança mão de recursos externos para tentar perpetuar os seus saberes. Enquanto isso, a geração continua a repetir, num país dos homens-livros fragmentado, os textos que preencheram as noites de casa cheia, quando o artista era soberano e a plateia podia transbordar seus sentimentos.

Para concluir essa reflexão sobre oralidade e memória circense, é preciso destacar fato recente em que a memória escrita do circo-teatro emergiu a partir da pesquisa acadêmica realizada com base primária nas próprias peças encenadas nos circos, presentes no Arquivo Miroel Silveira. No entanto, um acervo não fala por si só. Depende de análise e interpretação teórica, de investigação e comparação, da perseguição de vestígios que levem ao passado e apontem para o futuro, que aliem oralidade e registro escrito, teoria e empirismo. Nesse sentido, a memória, que de evocação se tornou cultura, passa, enfim, a se transformar em conhecimento. Na sintaxe de Fahrenheit 451, usada no início do artigo, é o processo coroado pela inversão: o que foi criado para coibir preserva. Como num espetáculo de circo-teatro, a trama se amolda às circunstâncias, agrega personagens, e se transforma. Recursos que, por fim, não irão impedir que a plateia continue se emocionando.

\title{
REFERÊNCIAS BIBLIOGRÁFICAS
}

BARTHOLO, Ruy. Respeitável público: os bastidores do fascinante mundo do circo. Rio de Janeiro: Letras \& Expressões Editora, 1999.

BOSI, Ecléa. Memória e sociedade: memória de velhos. São Paulo: Companhia das Letras, 1979.

COSTA, Cristina. A milésima segunda noite. São Paulo: AnnaBlume, 2000.

20. NETO, op. cit., p. s/n. 21. ORFEI, op. cit., p. 240.
COUTINHO, Romano. Honrarás tua mãe. Parte integrante do Prontuário 1286 do Arquivo Miroe Silveira da ECA/USP. 
MAGNO. Maria Ignês Carlos. Fahrenheit 451. Escritores da liberdade e uma discussão sobre leitura, escrita, imaginação, resistência e liberdade. Comunicação \& Educação, ano XIV, n. 1, jan./abr. 2009. São Paulo: CCA-ECA-USP/Paulinas.

MILITELLO, Dirce Tangará. Picadeiro. São Paulo: Edições Guarida, 1978.

. Terceiro sinal. São Paulo: Mercury Produções Artísticas, 1984.

NETO, Tito. Minha vida no circo. São Paulo: Editora Autores Novos, 1986.

ORFEI, Alberto. O circo viverá. São Paulo: Mercuryo, 1996.

SEYSSEL, Waldemar. Arrelia e o circo. São Paulo: Melhoramentos, 1977.

. Arrelia, uma autobiografia. São Paulo: Ibrasa, 1997.

SILVA, Ermínia. O circo: sua arte e seus saberes. O circo no Brasil do século XIX a meados do XX. Dissertação (Mestrado). Departamento de História do Instituto de Filosofia e Ciências Humanas da Universidade Estadual de Campinas, 1996.

SILVEIRA, Miroel. O circo: espaço arquetipal convergente. In: O circo. Secretaria da Cultura, Ciência e Tecnologia do Estado de São Paulo, 1978. 


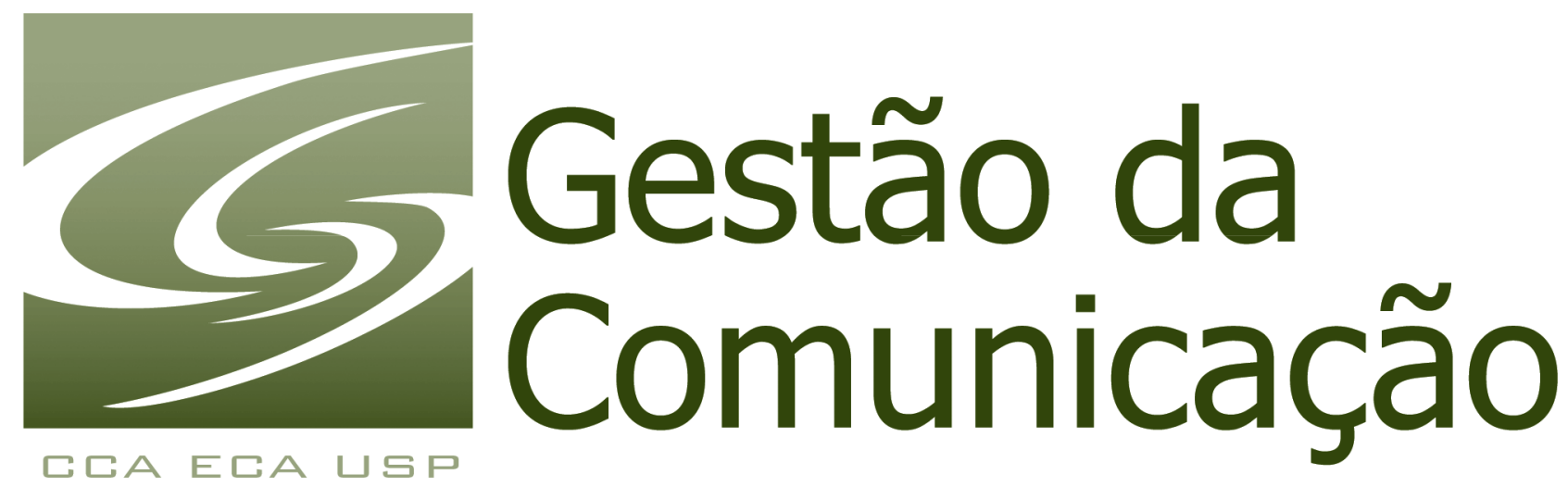

\section{Curso de Pós-Graduação Lato Sensu \\ - mais experiente e ałualizado Curso de Especialização em Comunicação da USP}

\section{Curso de Gestão da Comunicação: Políticas, Educação e Cultura \\ O gestor da comunicação planeja e executa projetos de comunicação em empresas privadas, instituições públicas ou movimentos comunitários nas áreas educacional, empresarial ou artístico-cultural.}

Duração: três semestres

Pré-requisito: formação superior (qualquer área) Seleção: prova escrita, entrevista e plano de estudo

\section{Processo Seletivo Semestral}

10 semestre: turma com aulas de segunda a quarta-feira 20 semestre: turma com aulas às sextas-feiras e aos sábados.

\section{Objetivos e Diferenciais}

- Capacitação do aluno para elaborar, implantar, avaliar e reestruturar projetos de comunicação/ cultura.

- Integração teórico-prática da área de comunicação com o mercado de trabalho.

- Formação humanística e profissional sólidas, baseada na inter-relação comunicação/cultura/ artes.

- Qualificação do profissional, preparando-o para compreender o mercado emergente, em constante transformação, e agir sobre ele.
Informações

$(+5511)$ 3091-4341

(+5511) 3091-4867

www.eca.usp.br/gestcom

gestcom@usp.br

\section{Endereço}

Av. Prof. Lúcio Martins

Rodrigues, 443, sl 209

Cidade Universitária São Paulo SP 